砂れき堆の形成による護岸近傍の局所洗掘

Local Scour Near Revetment Caused by Bars

$\begin{array}{llr}\text { 建設省土木研究所 } & \text { 正員 } & \text { 福岡捷二 } \\ \text { 建設省土木研究所 } & \text { 正員 } & \text { O浅野富夫 } \\ \text { 建設省土木研究所 } & \text { 正員 } & \text { 林 } \text { 正男 }\end{array}$

1.はじめに

直線河道においても，砂れき堆の形成に伴い流れの集中が生じ，その結果護岸近傍に局所洗掘が発生する ことが多い。したがって, 護岸の設計においては, このような局所洗掘の範囲と洗掘深の大きさをあらかじ め予测しておく必要がある。前者については，現在の河床状況からある程度予想することができるものの， 後者については洪水中の河床高を測定することが困難なため, 洪水中の洗掘深を測定することは容易でない。 さらに, 洪水時河床高の予测は, 護岸の設計においてだけでなく, 既設護岸の安全度評価を行う場合にも重 要となるものである。このような状態に呼応して, 近年単列砂れき堆(交互砂州)の波高に関する研究1)〜3) が数多く行われるようになり，波高と河道特性との関係が明らかにされてきた。しかしながら，実河道にお いては, 単列砂れき堆のみでなく種々の河床形態が存在し, 河床変動の不規則性・不確実性む局所洗掘深の 評洒に関係する。

このような状況に鑑み，著者らは既報4)において，単断面河道の多列砂れき堆の形成に伴う局所洗掘をも 対象として，川幅・水深比の範囲を広くとった実験的検討を行った。しかしながら，そこでは局所洗掘深の 分布特性に関する検討に不充分さが残っていた。本報告においては，先の検討で用いた個々の実験值に立ち 㷌り，検討を行うとともに新たに実験を行い，局所洗掘深の分布特性について詳細な検討を加えた。さらに， 複断面河道の局所洗掘及び，また単断面河道の局所洗掘に及ぼす護岸法面勾配の影響について屯同様の検討 を加えた。このようにして得られた局所洗掘の分布関数を用い,さきに提案した局所洗掘の発生確率の概念 ${ }^{4}$ を用い護岸近傍の局所洗掘予測手法の確立を図った。

2. 検討方法

一般に, 局所洗掘は洪水時において著しく, 護岸・根固めの安全性を検討する場合には, 洪水時の洗掘深, すなわち最深河床高が重要となる。しかしながら，現地河川において洪水時に河床高の分布あるいは時間的 変化を测定することは容易でなく，また低水時における定期横断測量成果は，洗掘箇所の洪水減水期以後の 埋め戻しにより，洪水時の河床高を適切に表しているとは限らず，むしろ洪水時における局所洗掘を過少評 価する傾向にある。図-1は，代表的な急流大河川下流部の模型を用いて得られた結果を示したものである。 図中に併示された洪水流のもとで, 最深河床高は洪水前よりも最大 $6 m$ 程度む低下し, これが洪水後 $4 \mathrm{~m}$ 程度埋 め戻されている。洪水直後に存在していた局所洗掘箇所は, 通常の定期横断測量時までに, さらに埋め戻さ れるものと推測される。

したがって，本研究では洪水中の局所洗掘の把握を目的として，水路実験において河床高の時間的・空間 的分布特性を通水中测定し, その結果を用いて, 護岸前面の局所洗掘と水理条件・河道条件との関係を把握 する方法を採用した。

実験条件の選定にあたっては，現地河川との相似性に充分配虑するとともに，実験結果の適用範囲を明確 にしておく必要がある。いま, 建設省直轄57河川から164区間を選定し5), 平均最大流量流下時における4種 の無次元量, すなわち川幅・水深比B/H, 無次元掃流力 $\tau *$, 水深・粒径比 $H / \mathrm{dm}$ 及び流速係数 $\psi$ の分布を検討 すると，約45\%区間に相当する $\mathrm{dm} \geqq 20 \mathrm{~mm}$ 河道を対象とした場合，各種無次元量の轮囲は比較的限定される。

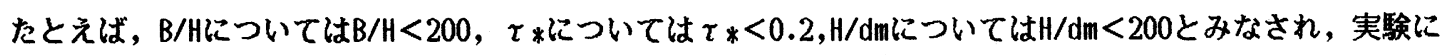
おいてむこのような筙囲を拯力满足させることが望ましい。また，実験精度の向上及び流速係数せの相似性 を考虑すると, 小規模河床波（砂漣・砂堆等）が発生しないことが好ましい。したがって, 本研究ではdm= 


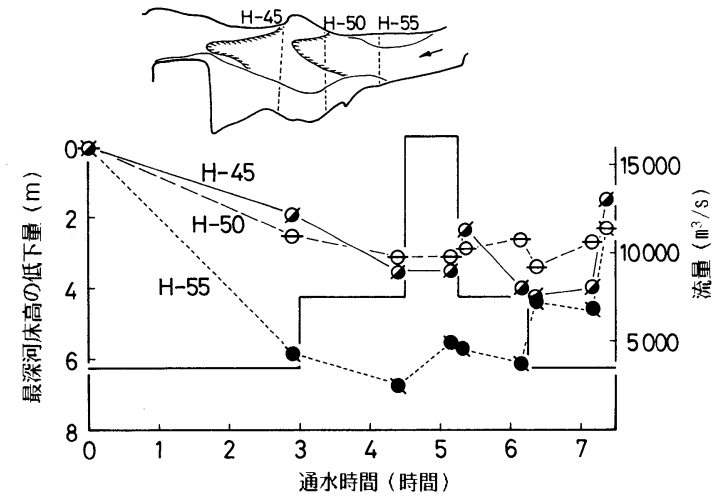

図-1 洪水時における最深河床高の低下

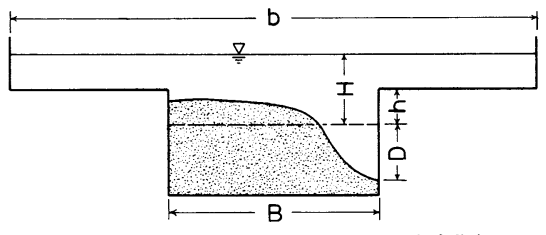

図-2 複断面河道の局所洗掘

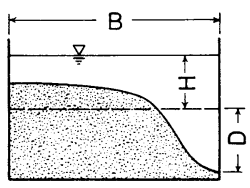

図-3 単断面河道の局所洗掘

表-1 実験水理条件

\begin{tabular}{c|c|c|c|c|c|c|c}
\hline 実験 & 断面形状 & 水理条件 & $\bar{\tau}^{\prime}-$ 擞 & 流量 $(1)$ & 水深 $(\mathrm{cm})$ & 平均流速 $(\mathrm{cm} / \mathrm{s})$ & 水路床勾配 \\
\hline I & 单断面 & 28 種 & 756 & $0.7 \sim 9.0$ & $0.6 \sim 3.4$ & $12 \sim 54$ & $1 / 50 \sim 1 / 280$ \\
\hline II & 单断面 & 8 種 & 288 & $3.0 \sim 6.0$ & $1.2 \sim 2.3$ & $32 \sim 50$ & $1 / 100$ \\
\hline III & 複断面 & 24 種 & 1152 & $0.7 \sim 15.0$ & $0.7 \sim 2.9$ & $15 \sim 43$ & $1 / 100$ \\
\hline
\end{tabular}

$1.0 \mathrm{~mm}$ 及び $1.5 \mathrm{~mm} の$ 均一砂を用い，表-1に示されるような条件のもとで実験を行った。

単断面河道に関する実験においては, 幅 $\mathrm{B}=0.6 \mathrm{~cm}$, 長さL $=30 \mathrm{~m} の$ 銅製両面ガラス張りの可変勾配水路が用い られている。平均流速Um, 河床勾配 $1 \mathrm{~b}, \mathrm{~B}, \mathrm{H}, \mathrm{dm}$ そついて, 実験における水理量の範囲と現地の水理量の範 囲とを比較すると，本実験結果は実験水路の 200 倍程度の規模を有する河道，すなわち $B<150 \mathrm{~m}, H<8 \mathrm{~m}$, $20 \mathrm{~mm} \leqq \mathrm{~d}<200 \mathrm{~mm}, 1 / 50 \leqq I_{b}<1 / 3000$ 河川に適用されることにある。したがって, 本研究で得られた成果を このような範囲を越える河川に適用する場合, さらに検討が必要とされる。

さらに，現地河川を対象とした場合，図-2のような複断面形状を有する河道が多い。いま，直轄40河川か ら抽出した73地点について, 低水路幅・低水路满杯水深比B/Hをを算定すると, ほとんどの值が $25 \leqq B / H<95$ の範囲に合まれている。したがって, 本研究においては, 低水路幅・全川幅比を代表的な值である $B / b=0.4$ に固定し， dm=1.0mmの均一砂の敖き均し高さを調整することにより，25ミB/H<95の範囲を対象として,表-1 に示されるような実験を実施した。なお, 実験においては, 水路幅 $3 \mathrm{~m}$, 長さ50mの可変勾配銅製水路内に, $b=150 \mathrm{~cm}, B=60 \mathrm{~cm}, \mathrm{~L}=30 \mathrm{~m}$ 複断面水路を耐水合板で製作し, 高水敷には低水路と同一の砂粒を貼付した。本 実験においても，現地河道におけるdm及びUmの範囲に対する考虑より，上記単断面河道の場合と同様に，本

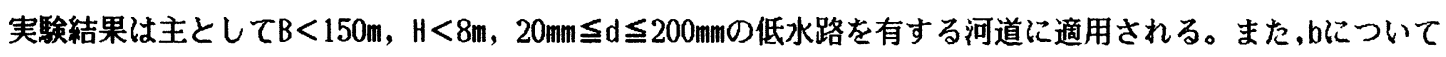
はB/b=0.4としており, $b<300 \mathrm{~m}$ に相当している。先に示した $\mathrm{dm} \geqq 20 \mathrm{~mm}$ の河道では, 約 $80 \%$ 河道において $\mathrm{b} \leqq 300 \mathrm{~m}$ となっおり，本実験結果は多くの複断面急流河川に適用されるものと推測される。

いずれの実験においても，土研式あるいは予借実験に基づき給砂を行うとともに，通水を継続しながら河 床高の测定を数断面で一定時間間隔( 5分〜15分)で行い, 実験値の数を增加させた。また, 本研究では砂れ き堆の形成に伴う局所洗掘を対象としており, 解析にあたっては, 通水後数時間を経過して砂れき堆が充分 に発達した後の実験値を採用している。

\section{3. 解析方法}

本研究では, 種々の局所洗掘特性のうち, 図-3に示されるように, 対象とした横断面の平均河床高と最深 河床高との差で与えられる局所洗掘深Dに着目し, これを当該断面の平均水深Hで無次元化し, 検討を加える こととする。 
従来より，局所洗掘深に対する第一因子としてB/Hを取り上げることが多く，本検討においても，まずB/H の值を限定し, 局所洗掘深・平均水深比D/Hの值について，その分布を検討すると以下のようである。D/Hは 必ず正の值をとり，また実際現象を考虑すると極めて大きな值もとり得ないことより,D/Hの分布として両側 有限の対数正規分布が想定される。両侧有限対数正規分布を適合させる場合，個々の実験值Di/Hi $(i=1,2, \cdots$, n)を $\log X i=\log [(\mathrm{Di} / \mathrm{Hi}) /\{\mathrm{M}-\mathrm{Di} / \mathrm{Hi}\}]$ K変換する必要があり,上限值Mを設定しなければならない。このよう な場合， $\log X i か ゙$ 正規分布を呈するまで,すなわち $\log X i$ が正規確率紙上で直線分布となるまで, Mを試行錯 誤的に設定することにより，Mの值を確定させることができる。いま，単断面河道において, 河岸沿いに最深 部が生じた断面を対象として, 両側有限対数正規分布を適合させると図-4のようになり,D/Hは両側有限対数 正規分布を呈することが確認される。このような特性は, 他の場合にも同様であって,D/Hの分布特性仙両侧 有限対数正規分布を適合させたときの平均值，標準偏差，上限值によって規定されることが知られる。

なお，本論で対象としたdm $\geqq 20 \mathrm{~mm}$ の河川においては, $0.05 \leqq \tau * \leqq 0.15, H / \mathrm{dm} \leqq 400$ 範囲内で， $\tau *$ 及びH/dm の影響はB/Hに比して相対的に小さく4)本検討においてはB/HのみによってD/Hの特性を評価することとする。 また, 河川管理上重要となる局所洗掘は河岸近傍に発生するものであり, 以後においては水路側壁面沿いに 河床の最深部が発生した実験值に限定して検討を行っている。

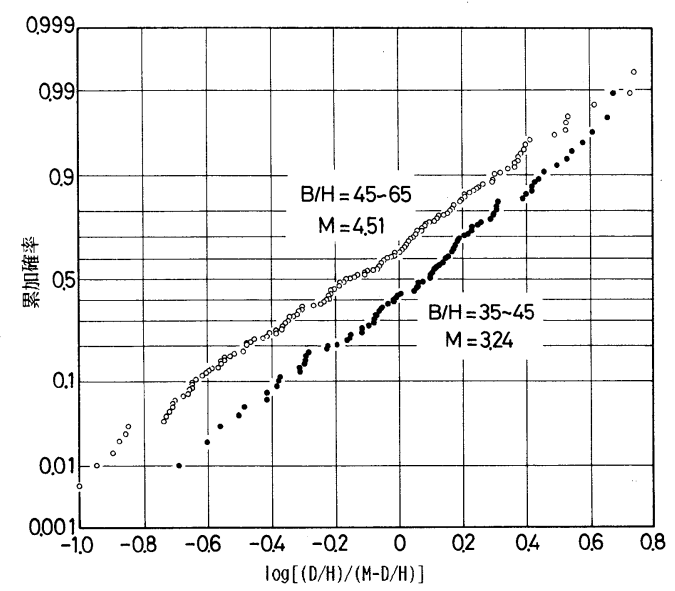

図-4 局所洗掘深・平均水深比の分布特性

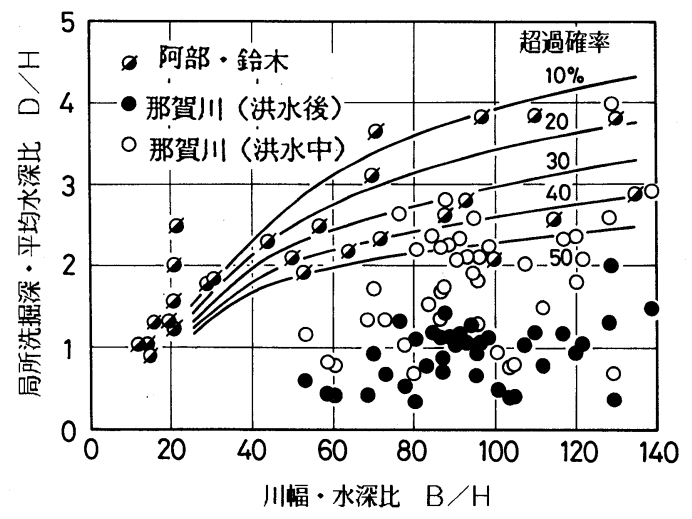

图一 - 超通確率を考虑した局所洗掘深・平均水深比

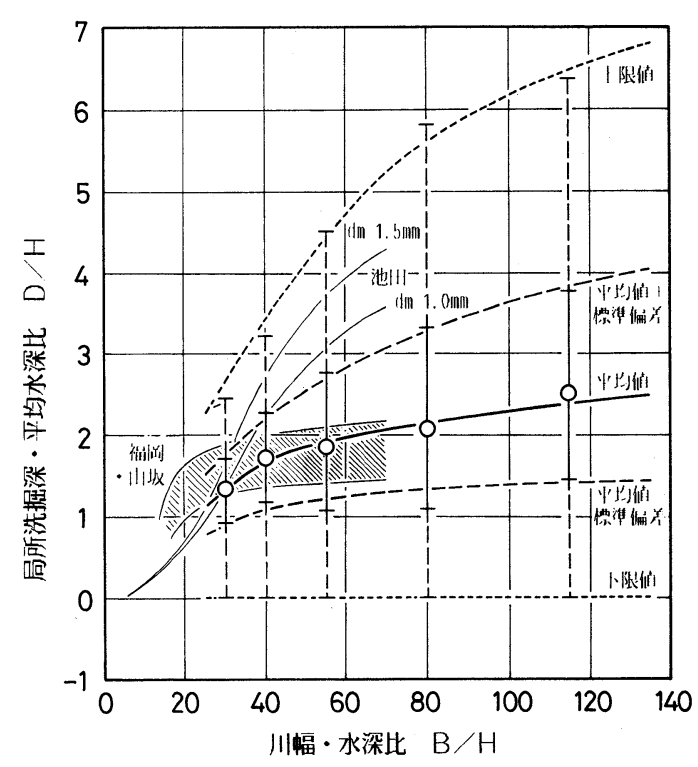

図-5 局所洗掘深・平均水深比と川幅・水深比

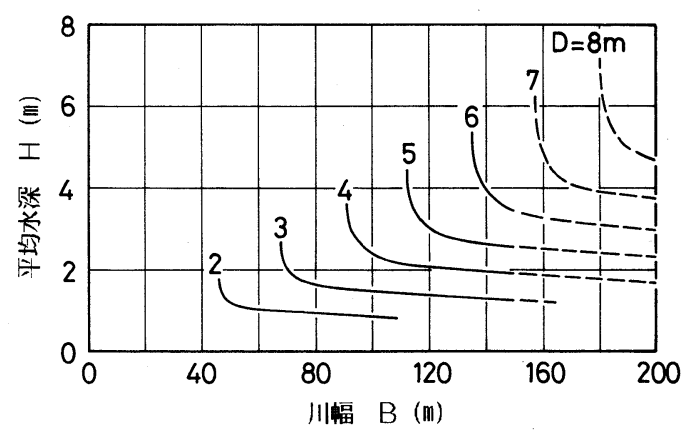

図-7 単断面河道の局所洗掘深 


\section{4. 単断面河道における局所洗掘深特性}

(1) 単断面河道の局所洗掘深

図-4において例示したように,D/Hの分布に対する両側有限対数正規分布の適合性は極めて高い。この分布 よりD/Hの平均値及び標準偏差を算定し，B/Hに対して図示すると図-5のようになる。図において，平均值は B/Hの増加とともに増加するものの，増加の割合はB/Hの増加につれて小さくなっている。また，標準偏差む B/Hの增加とともに大きくなり，B/Hが大きくなるとD/Hの分布は広くなることが知られる。

以上のように，DはHに比例せず,Dの特性はB/Hによって異なる様相を呈している。すなわち，Hが同一であ ってもBが異なる場合,Bの大きい断面の方がDは大きくなることが同われる。これは，単列砂れき堆を有する 直線河道における局所洗掘は，砂れき堆の形成に伴う流れの集中によって生じ，Hが同じ場合，その集中はB が大きい方が相対的に著しいことを意味している。すなわち，局所洗掘箇所の単位幅流量が大きくなる可能 性はBが大きい方が高く，その結果Dの值む大きくなるむのと解される。しかし，流れの集中によって単位幅 流量が増加する割合は，Bに比例するほどではなく，Bの増加とともに減少していき，Dの増加割合むBの増大 とともに減少するものと考えられる。このようなBの増加に伴う流れの集中化は，Bがさらに増加して複列砂 れき堆あるいは多列砂れき堆が形成されるようになっても継続し，Bの増加に伴いDは増大するという特性を 有している。なお，Dの分布幅はBが大きくなるほど広くなるが，これはB/Hが大きくなると, 河床形態が単 列から多列砂れき堆へと移行し，横断形状が次第に多様化することによるものと解される。

図-5には, 池田2)が次元解析の手法を用いて実験值を整理して求めた D/Hの推定值が併示されている。池 田の推定值は，ある区間における最大局所洗掘深に関する実験結果に基づくものであり， $3<\mathrm{B} / \mathrm{h}<70 に$ 対し て与えられている。さらに,図-9には福岡・山坂3)の理論式によるD/Hの範囲が示されている。実河川との相 似性に配虑して，B/Hの範囲を広くした実験を行った本結果は，20<B/H<70の範囲において池田の推定值及 び福岡・山坂の理論值と同様の傾向を示している。ただし，池田及び福岡・山坂は砂れき堆による局所洗掘 深の最大值を与えており，本結果よりも若干大きな值となっている。

(2) 単断面河道における局所洗掘深の予测方法

図-6は，図-5に示されたD/Hの平均值及び標準偏差から得られるD/Hの分布形に基づき，種々の超過確率に おけるD/HとB/Hとの関係を示したものである。図-6を用いると,以下のようにして局所洗掘深Dを予測するこ とができる。すなわち，まず河道の線形及び現在の局所洗掘の状況に応じ，基本高水流量策定と同様に,D/H の超過確率を設定する。つぎに，当該断面の計画水位に基づき川幅B及び平均水深肘算定し，図-6を用いて D/Hの予測值を求めることによりDを推定することができる。

さらに，図-6には阿部・鈴木6)の実験結果及び横断面形状が比較的単断面に近い那賀川（2.0km〜10.0km） における测定結果が併示されている。阿部・鈴木は, $B=0.4 \sim 2.0 \mathrm{~m}, \mathrm{I}_{\mathrm{b}}=1 / 30 \sim 1 / 120, \mathrm{dm}=1.0 \sim 3.2 \mathrm{~mm}$ の均一砂 を用い，通水中河床高の测定を行い，実験区間内において生じた数個の砂れき堆を対象として最大局所洗掘 深Dmax/Hを検討している。那賀川では，昭和51年 9 月の出水 $\left(Q_{\max }=4.315 \mathrm{~m}^{3} / \mathrm{s}\right)$ を対象として，その痕跡水位 と昭和52年12月に実施された横断测量成果とに基づき，D’/Hが算定されている。また，図-1に例示されたA 川の模型実験では,洗掘が生じた10断面における洪水中の局所洗掘深Dと淇水直後の同所洗掘深D’との比がほ ぼ 2であったことより, 洪水中の推定值はD/H=2D'/Hとして算定されている。図-6において,本検討で得られ たD/Hの特性は，実験結果及び現地観測值の傾向をよく表現しているものと判断される。

つぎに, 川幅B, 平均水深Hの単断面河道における局所洗掘深Dの一例として, 超過確弯 $50 \%$ の值を例示する と図-7のようになる。図-7は, 種々のDとHとに対して, 図-6の超過確率50\%の曲線より所定のD/HとなるB/H, すなわちBを算定することにより描かれたものである。先に示したように，本実験結果はB $<150 \mathrm{~m} の$ 単断面河 道を対象としたものであり，この範囲を越える領域のDについては，図-7において破線で示されている。

（3）局所洗掘深に及ぼす檴岸法面勾配の影䈉

単断面河道において, 護岸法面の勾配が護岸沿いの局所洗掘深に与える影響を検討すると以下のようであ 

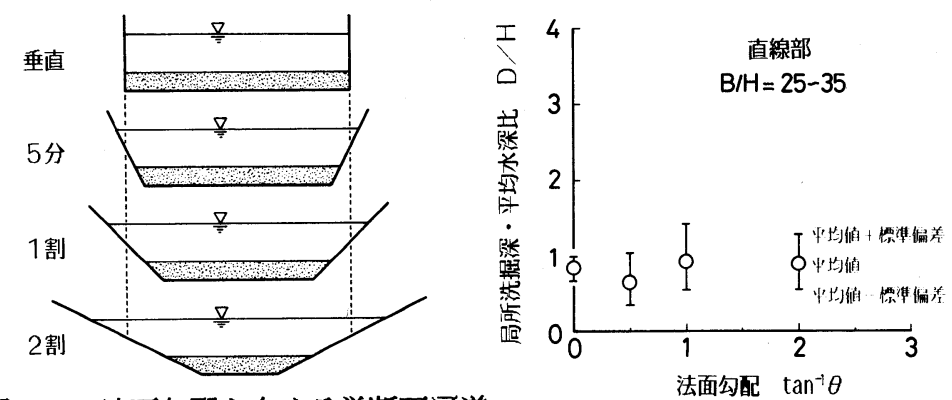

図一８法面勾配を有する単断面河道

图-9 法面勾配と局所洗掘深

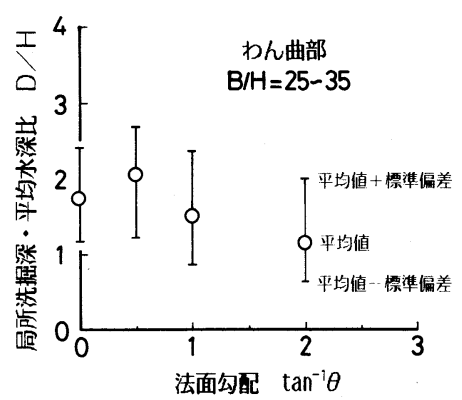

る。図-9は, 図-8に示されるような直線水路において, 移動床部の平均河床高より算定したH及びDに基づき 評価したD/Hについて，両侧有限対数正規分布を適合させたときのD/Hの平均值及び標準偏差を,4種の法面勾 配(垂直,5分,1割,2割)に対して示したものである。なお,水路幅Bは水面幅と移動床部の幅との平均值で示さ れており,いずれの場合にもB 法面勾配に係りなくほほ一定值を呈しており,法面勾配は局所洗掘深口にあまり影響していないことが知られ る。したがって, 直壁河道を想定した長方形断面水路における結果は,2割程度までの法面勾配を有する河道 にも，そのまま適用されることになる。

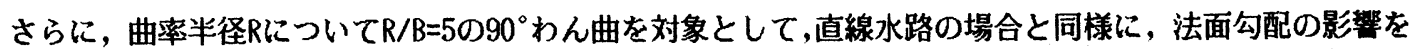
検討すると図-10のようになる。図に示された值は，わん曲始端から $45^{\circ}, 60^{\circ}$ 及び $90^{\circ}$ の断面における測定値 より得られたものであって,わん曲部においては法面勾配が緩くなるとともにDは減少することが確認される。 5. 複断面河道における局所洗掘深の特性

(1) 複断面河道の局所洗掘深

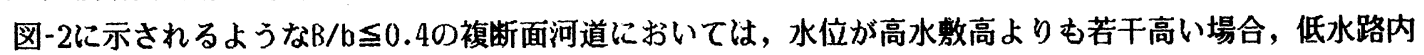
の流れと高水敷上の流れとの間に生ずる混合は著しくなり, その結果流れの抵抗（合成粗度係数）は大きく なることが知られているワ)。低水路と高水敷間の流れの混合は低水護岸近㥬の局所洗掘にも大きく係ってい るむのと推定され，以下においてはこのような観点から検討を行う。

単断面河道の場合と同様に, 複断面水路について種々の低水路幅·低水路满杯水深比B/Hに関する実験值を, 低水路平均水深·满杯水深比 H/hの值により分類し, D/Hの分布に両侧有限対数正規分布を適合させ, D/Hの平 均值及び標準偏差を求めると図-13のようになる。図にみられるように, 複断面河道の場合, H/hの增加に伴 うD/Hの変化の様子は, $\mathrm{B} / \mathrm{h} \leqq 45$ 場合と $\mathrm{B} / \mathrm{h}>45$ 場合とで異なっている。すなわち, 前者の場合, D/Hは単 調に減少し,D/HはB及びHをそれぞれ川幅及び水深とする単断面河道とする破線の值に較べ小さくなっている。 これに対し, 後者の場合, H/hの増加とともにD/Hは増加し, 単断面河道の場合よりも大きくなり,さらにH/h が増加するとD/Hは減少傾向に転じている。これは, 前者の場合には流れ場の水平スケールに較べ鉛直スケー ルが大きいため, 相互干涉に伴う混合の影警が低水路河床面までは及ばないのに対し，後者の場合には鉛直 スケールが相対的に小さいため, 混合の影響が河床面にまで及び, その結果局所洗掘はBを川幅, Hを水深と する単断面河道の場合よりも大きくなるものと解される。なお, D/Hが最大となるH/hは, 合成粗度係数が最 大となるH/hにほぼ一致しており,局所洗掘に流れの混合が大きく係っていることが確認される。水位が高く なると,このような混合は相対的に弱まり，またB/Hが小さい場合,混合の影锌は河床面にまでは及ばなくなる ものと推定される。

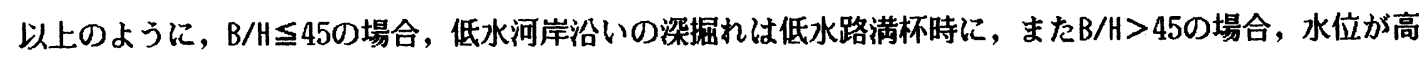
水敷高よりも高い時に, それぞれ最む著しくなっている。複断面河道の局所洗掘特性は, 低水路内の流れと 高水敷上の流れとの間の相互干渉に伴う混合と大いに係っているため, 本実駼結果は水位の增加に伴う合成 粗度係数の增加が認められるB/b 0.4 複断面河道にも適用されるものと推测される。 


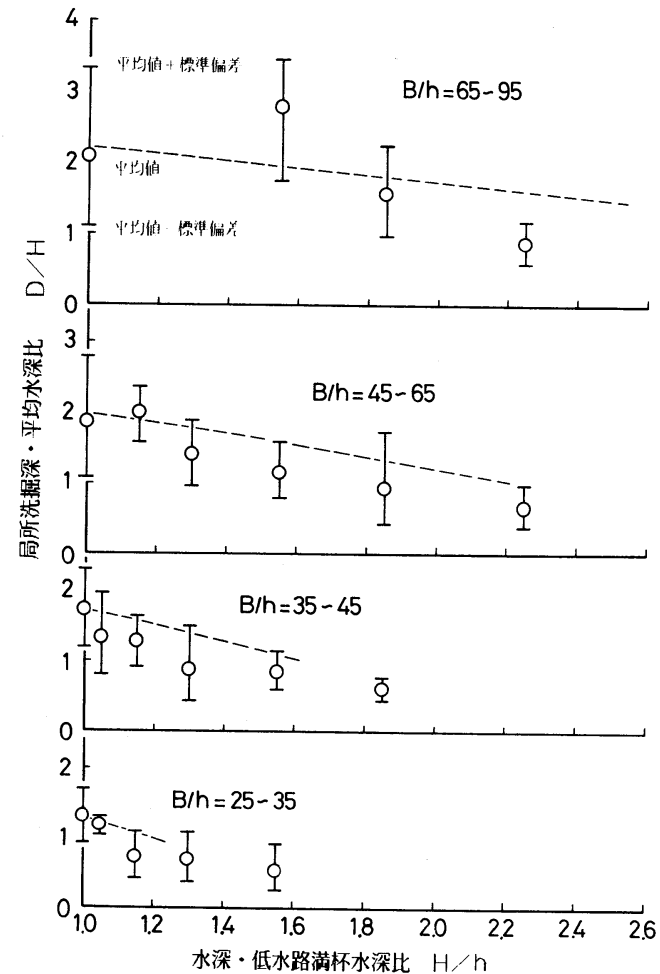

図-11 複断面水路の局所洗掘深・平均水深比

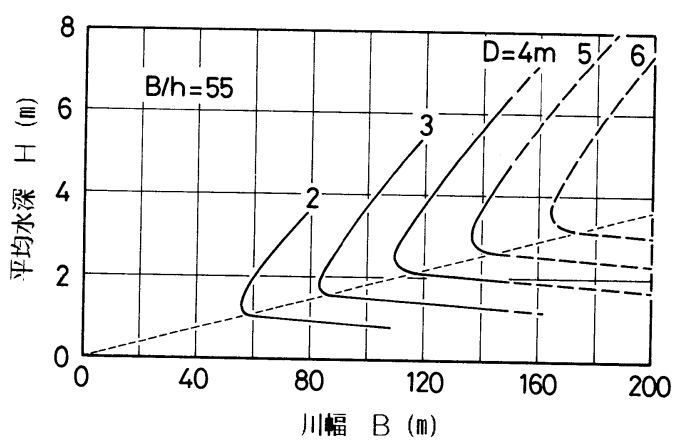

図-12 複断面河道の局所洗掘深 $(B / h=55)$

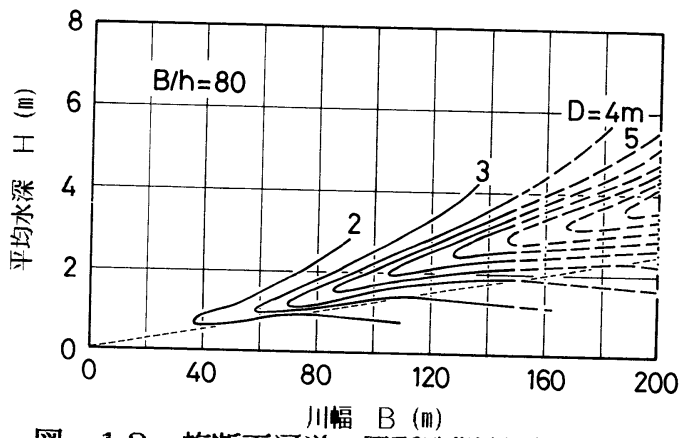

図-13 複断面河道の局所洗掘深 $(\mathrm{B} / \mathrm{h}=80)$

（2）複断面河道における局所洗掘深の予测方法

$\mathrm{B} / \mathrm{h} \leqq 450$ 複断面河道においては，低水路满杯流量時にDは最大となり，単断面河道の場合と同様にして， Dの予测值が得られる。 $\mathrm{B} / \mathrm{h}>45$ の河道においては,水位が高水敷高より高い場合にDの最大があらわれる。た

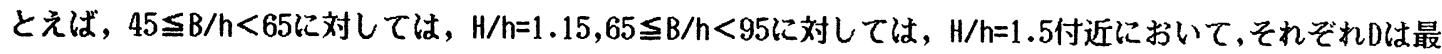
大となる。したがって，B/h>45の場合，設計水位に基づき $\mathrm{H}$ 設定し，B/Hの值を用いて単断面河道の場合 を同样にしてDを算定し，これに割増係数を乗ずることにより複断面河道におけるDの予測值が得られる。割

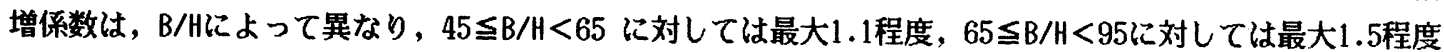
と見込まれる。なお，割増係数はH/hの值によっても異なるため, 簃密には図-11より妥当な割増係数を算定 する必要がある。

図-12及び図-13は, それぞれ，B/h=55及びB/h=80の複断面河道について，図-7の場合と同様にして，種々 のB，Hのもとで超過確蜜50\%のDを示したものである。図中の細破線は，それぞれB/h=55及びB/h=80を满足す る低水路满杯水深を表しており,Hがこの細破線より小さな領域については，単断面河道に関する図-7の値が 示されている。

参考文献：1)藤田裕一郎・村本嘉雄・堀池周二・小池剛:交互砂州の発達機楆,第26回水理講演会論文集,pp.25 ～30,1982. 2)池田駿介:単列交互砂州の波長と波高:第27回水理講演会論文集,pp.689〜695,1983. 3)福 岡捷二:山坂昌成:河床形状・流れ・流砂量の非線型関係を考虑した交互砂州の平衡波高の理論,土木学会論文 集,第357号/II -3,pp.45〜54,1985.4)橋本宏·浅野富夫・林正男:河岸近傍の局所洗掘に関する実験的検討， 第29回水理講演会論文集, pp.567 572,1985. 5)建設省河川局治水課·土木研究所河川研究室: 蛇行現象と 河道計画, 1982.6)阿部宗平·鈴木浩之:流路工計画の横工に関する実験的考察,土木技術資料,第 25 巻,第 1 号, $p$ p.44 49,1983.7)福岡捷二・浅野富夫·藤田光一・坂野章: 複断面河道における洪水流の抵抗特性, 第30回水理 講演会論文集,pp.499〜504,1986. 